\title{
Construindo "ELES": A NECESSIDADE DE PERCEBER O "OUTRO" EM UM MUNDO ENTÃO “NOSSO”
}

\author{
Héder Junior dos Santos ${ }^{1}$ e Luana Hordones Chaves ${ }^{2}$
}

\begin{abstract}
Resumo
Esse artigo propõe uma leitura do filme Yasmin (Inglaterra/ Alemanha, 2004), dirigido por Kenneth Glenaan, que tem por temática a inserção de imigrantes paquistaneses alocados na Inglaterra do início do século XXI, os quais são diretamente afetados pelas reverberações do ataque terrorista às torres gêmeas de Nova Iorque. Tratando da dificuldade de adaptação desses imigrantes por razões de identidade cultural, assim como por sua condição socioeconômica na sociedade inglesa, a narrativa sugere relações sociais que, senão problemáticas, parecem ser estabelecidas de forma frágil entre o "eu" inglês e o "outro" paquistanês: o que é evidenciado após o 11 de setembro de 2001.
\end{abstract}

Palavras-chave: 11 de setembro. Cinema e sociedade. Orientalismo. Preconceito étnico-religioso.

\section{Constructing “Them”: The Need to Perceive the "Other" in a World Once "Ours"}

\begin{abstract}
This article proposes an interpretation of the film Yasmin (England/ Germany, 2004), directed by Kenneth Glenaan. The film explores the question of the inclusion of Pakistani immigrants in England at the beginning of the Twenty-First century. These people are directly affected by the reverberations of the terrorist attacks to the twin towers in New York. The narrative deals with the adaptation difficulties of these
\end{abstract}

\footnotetext{
${ }^{1}$ Mestrando em Letras pela Universidade Estadual "Julio de Mesquita Filho" - UNESP/Assis, Brasil. heder_eu@hotmail.com

${ }^{2}$ Doutoranda em Sociologia pela Universidade Federal de Minas Gerais, Brasil. luanahordones@ hotmail.com
} 
immigrants due to cultural identity issues, as well as their socio-economic condition in the English society. The film also suggests social relations that seem to be weakly established between the "English I" and the "Pakistani other": which are evidenced after the events in "September 11 2001".

Keywords: September 11. Cinema and society. Orientalism. Ethnicities and religious prejudice.

\section{INTRODUÇÃO}

0 filme Yasmin (2004), dirigido pelo escocês Kenneth Glenaan, tematiza a condição de imigrantes paquistaneses, moradores de um vilarejo pobre da Inglaterra no início do século XXI, que são fortemente afetados pela repercussão do ataque terrorista às torres gêmeas de Nova Iorque. Trazido para a narrativa fílmica, o fato histórico constitui-se como o nó górdio, tornando-se 0 elemento catalisador através do qual a trajetória das personagens será marcada: 0 antes e o depois de 11/09. Tal acontecimento produz reverberações na sociedade inglesa, afetando essencialmente a vida desses imigrantes. A película trata da condição de imigrantes de tradição islâmica em um país europeu no momento histórico em que as relações, anteriormente problemáticas, entre o "Ocidente" e 0 "Mundo Muçulmano"3 sofrem uma agudização radical. Tais relações de preconceito étnico-religioso são representadas de forma recorrente, sendo válido notar como o cinema apreende a matéria ${ }^{4}$.

0 cinema, como qualquer forma de linguagem artística, compõe vocalizações a partir de uma perspectiva. Na obra, está presente um olhar que obedece a critérios formais que lhe são próprios, mas que notadamente são regidos

\footnotetext{
3 "Ocidente" e "Mundo Muçulmano" entre aspas remetem às construções e às formas de representação de dois cenários que se diferenciam culturalmente, segundo as reflexões de Edward Said (1990). 0 autor trabalha o conceito de "orientalismo" que, a seu ver, remete a uma forma de compreensão e de estudo regularizado ou "orientalizado" dominado por imperativos, perspectivas e preconceitos político-ideológicos que foram adequados ao Oriente. Sendo um produto de forças e interesses políticos, o "orientalismo" apresenta o Oriente, e por consequência o mundo muçulmano, como um sistema de representações dentro de um conjunto de forças que acabaram por introduzi-los na consciência e na cultura ocidental.

${ }^{4}$ Torna-se significativo para o desenvolvimento desse trabalho, o fato de Yasmin (2004) reler 0 ataque às torres gêmeas tomando como matéria a trajetória de sujeitos contextualizados numa comunidade de tradição islâmica situada na Inglaterra dos "dias de hoje", e não encalçado às personagens norte-americanas recepcionando o fato em seu solo, como foi recorrente no cinema estadunidense, em tese, de alcance mundial, como são exemplos: Fahrenheit 9/11 (2004), do cineasta norte-americano Michael Moore, World Trade Center (2006) do também norteamericano Oliver Stone, e Voo United 93 (2006) do inglês Paul Greengrass.
} 
por elementos sociais. Sobre essa questão, o estudioso Ismail Xavier (1977) nos ensina que a maneira de se montar um filme - elegendo determinadas cenas, ao passo que se descartam outras, estabelecendo a partir daí certa sequência ${ }^{5}$ - aspira à "realização de certo objetivo sociocultural tomado como tarefa legítima do cinema" (XAVIER, 1977, p. 10). Sendo assim, poderíamos rastrear uma ideologia seminal em cada realização cinematográfica. Daí a importância da sociologia do cinema, cuja metodologia nos fornece instrumentos para captarmos o suporte ideológico imputado nos entre fotogramas. Ainda, segundo Xavier (1977), é o modo de pensar orquestrador, o sistema de ideias de base de cada narrativa que almejaria esclarecer, postular ou redesenhar fatos históricos, políticos e sociais: consecutivamente, por meio da elaboração de uma história, e encarnados na figura do narrador, já que é ele quem recorta aquilo que nos é apresentado. Só tomamos conhecimento do universo diegético segundo a instância narradora.

Dessa maneira, pode-se considerar que visão de mundo imputada no filme, no mais das vezes, se revela presente na própria sociedade de que parte 0 cineasta. 0 momento de realização da película se mostra pela perspectiva adotada pelo narrador social de cada obra, o qual pode ser caracterizado segundo as próprias imagens trazidas pela narrativa fílmica. Ou seja, temos a fiç̧ão como mediadora de verdades ou realidades mentais e sociais construídas historicamente. Ainda sobre a construção de um filme, importa mencionar que ele é formado, em termos criativos, na direção e na montagem, conforme já antecipamos; e podem ser divididos em: componentes dramáticos (décor, iluminação, personagens), componentes plásticos (planos, cenas, sequências, ligações, angulações e movimentos) e componentes estético-sonoros (diálogo, música, ruídos), uma vez que tais elementos dão a tônica do conteúdo imagético e reafirmam a postura do narrador social acerca daquilo que se dispõe a narrar.

A possibilidade de examinarmos o filme Yasmin (2004) não se justificaria apenas em notar como se dá a construção do olhar do narrador sobre a temática das relações conflituosas entre o "eu" inglês e o "outro" paquistanês, mas no próprio posicionamento da câmera, na composição das personagens, no tratamento das cenas (movimentação, duração, distribuição de elementos). Ou seja, a própria construção fílmica é objeto de nossa análise, pois, como observamos acima, esta comporta sempre um "objetivo sociocultural" (XAVIER, 1977, p. 10). Seguindo esta sugestão de análise cinematográfica, assumimos que não é possível nos

\footnotetext{
${ }^{5} 0$ presente artigo está de acordo com as novas regras de ortografia da língua portuguesa, no entanto, conservam-se nas citações diretas as estruturas gramático-ortográficas verificáveis nos originais consultados nesta pesquisa.
} 
depararmos com explicações sociológicas dadas de forma aberta e direta nos filmes, mas neles podemos verificar certo matiz discursivo, apto a comunicar uma visão de mundo pertinente ao momento histórico em que a película foi realizada, o que vem a corroborar as observações teórico-analíticas de Frederic Jameson (1995), particularmente aquelas de As Marcas do Visivel, quando profere que as películas, pensadas na sua particularidade e universalidade, acabam por dar pistas sobre a história contemporânea à produção da narrativa, já que a estética se (trans)forma de acordo com as condições históricas e conjunturais.

Feitas tais considerações, apresentamos a seguir o quadro arranjado pelo filme, no que toca à condição dos imigrantes muçulmanos alocados num bairro periférico da Inglaterra no século XXI.

\section{A família Houssain: o Hibridismo na CONSTITUIÇÃo DAS PERSONAGENS}

A narrativa se inicia com o desenho das condições das personagens antes do ataque às torres nova-iorquinas. A partir de uma possível relação amorosa com seu companheiro de trabalho, o filme mostra o conflito vivido por Yasmin (Archie Panjabi), personagem que dá título à obra, como uma mulher que transita entre duas culturas. Embora a personagem se enquadre no perfil das demais mulheres inglesas por trabalhar fora, vestir-se com jeans e dirigir seu próprio carro - o que poderia compor uma identidade aparentemente ocidental e moderna -, o foco narrativo expõe os limites a ela conferidos enquanto filha de um imigrante de família muçulmana e conservadora. 0 relacionamento com John (Steve Jackson) confirma os dilemas entre a vida pública e privada de Yasmin. A protagonista argumenta que espera resolver um "assunto familiar" para então ter condições de se envolver com John. Ela não esclarece que assunto seria este e John só descobre no final da narrativa que a amiga era casada. A protagonista que, apesar das liberdades conquistadas, não pode se casar por escolha própria, não esconde sua insatisfação com tal situação: o casamento com Faysal (Shahid Ahmed) é um acordo entre famílias e que fora imposto pelo pai.

Na loja de consertos de televisores e vídeos cassetes de Khalid (Renu Setna), a câmera parada aprecia o diálogo cômico, mas não menos crítico entre o pai de Yasmin e um amigo com traços orientais. Diversos discursos ocupam a cena. 0 locutor do rádio narra uma partida de futebol. Enquanto Khalid faz consertos, seu amigo lê o jornal tecendo algumas considerações sobre as notícias lá encontradas, frisando a má qualidade do futebol paquistanês: "críquete de aldeia", sentencia 
repetidamente a personagem, referindo-se à má qualidade do esporte, se comparado àquele praticado em outros países. Khalid faz consertos e solicita uma pequena chave. Não tendo o pedido atendido, o pai chama o amigo de "indiano surdo e agora idiota", apresentando sua nacionalidade seguida de adjetivos depreciativos. Embora tenhamos na cena um tom cômico, proveniente da discussão entre duas personagens mais velhas, a mesma não deixa de apontar a abertura do imigrante indiano para as práticas do tempo e espaço em que está alocado, reprováveis na visão conservadora do pai de Yasmin e Nasir. São duas visões antagônicas para sujeitos dispostos numa mesma condição de imigrantes. Ao comentar uma notícia de alguém "quase sem nenhuma roupa", Khalid rejeita a leitura:

Khalid: "Você não tem que ler isso."

Amigo: "É importante saber o que a geração mais jovem faz."

Khalid: "Se é isso que eles fazem, que Alá nos ajude." (YASMIN, 2004).

Dado o contexto da cena, podemos considerar que o filme já representa Khalid como um imigrante atento às suas raízes, observando com maus olhos algumas práticas ocidentais contemporâneas, principalmente aquelas desempenhadas pelas gerações mais novas, às quais pertencem seus filhos. A cena sugere a tensão entre essas diferentes cosmovisões. A partir do diálogo acima transcrito, notamos que o julgamento do pai é marcadamente constituído pela mediação religiosa, fomentadora de modelos morais específicos, norteadores da educação oferecida a Yasmin e Nasir, como é dado conhecer no decorrer do filme. Sendo assim, é simbólico que Khalid trabalhe no conserto de materiais usados. Em analogia a discurso advindo da tradição muçulmana que constitui a identidade de Khalid, é como se o narrador já sinalizasse que no pai encontraremos um sujeito que não descarta aquilo que está em desuso, mas que o instrumentaliza a fim de mantê-lo perene, em uso e vigilância, efetuando pequenos reparos, mas nunca rejeitando.

0 fim da tarde é o cenário dos poucos momentos de sociabilidade entre os membros da família. Conforme antecipamos, o casamento, que é fruto de um acordo entre as famílias, não deixa de comportar a ideia da migração para a Europa como possibilidade de um mundo de realizações, já que o filme enfatiza que Yasmin se separaria após a concessão do visto permanente de Faysal. Sendo assim, a narrativa traz num primeiro momento o elemento da migração ilegal nos países europeus na experiência do sujeito que procura espaço em sociedades nas que o mercado oferece melhores condições de trabalho, como no caso de Khalid 
que se mudou com a esposa para a Inglaterra com o sonho de construir uma "bela casa". Todavia, após o 11/09, esse movimento será tratado pelo narrador fílmico a partir de políticas públicas de anti-imigração e antiterrorismo.

A casa de Khalid é desenhada pelo narrador sob o signo da tradição e da manutenção dos valores muçulmanos, mas apresentando as rachaduras próprias de um espaço em que vários discursos buscam legitimidade. Todos estão reunidos na cozinha de Khalid. Yasmin chega e começa a cozinhar. Nesse momento, a película nos mostra como se dão as relações no interior da família Houssain e 0 papel da mulher nesse contexto de imigrantes. Ainda enraivecida, mas com o tom de voz mais baixo, em respeito à figura paterna, a protagonista pretensamente se levanta contra a lógica estabelecida, deixando clara sua condição de trabalhadora formal, questionando porque o irmão Nasir, de quem temos apenas informações superficiais nesse momento da narrativa, não poderia ao menos acender o fogão, ajudando nos afazeres cotidianos da casa. Khalid sugere que Faysal pudesse usar o carro de Yasmin para trabalhar como taxista, numa tentativa de instaurar a ordem do homem como o efetivo mantenedor da casa:

Pai: "Exibindo-se naquela coisa [carro]! Você envergonha a família. É o que você quer? Desgraçar o nome da família?"

Yasmin: "Casei com ele pelo nome da família, certo? Não preciso viver com os paquistaneses idiotas."

Pai: "Não quero linguagem chula nesta casa. Está entendendo?"' (YASMIN, 2004).

Enfoque no rosto entristecido de Yasmin, que passa as páginas de uma revista - elemento social por meio do qual estão dispostas as modernas formas de ser e estar no mundo ocidental - às quais parecem consolar a protagonista que sustenta um casamento em nome da ordem familiar. Com a chegada de Nasir em seu quarto, Yasmin fuma repetidos cigarros na tentativa de controlar a ansiedade, oriunda de um dia de trabalho, mas acentuadamente proveniente da discussão com o pai e de sua solidão. 0 conteúdo da conversa é Faysal. Nasir chacoteia 0 cunhado, chamando-o de "Import", ao passo que transmite a visão do pai de que Yasmin "Vai se acostumar", que "0 amor vai crescer como as árvores perto de um rio", reproduzindo de forma irônica e blasfêmica as palavras de Khalid sobre o casamento. No entanto, a personagem central sentencia: "Ele pode esquecer.

\footnotetext{
${ }^{6}$ Interpolação nossa.

${ }^{7}$ Tradução nossa: importado.
} 
Assim que ele [o marido] estiver legal, já era"8, reiterando sua posição no acordo matrimonial que se findaria com a concessão de visto permanente e com 0 consecutivo divórcio.

Ainda nesses momentos que antecedem ao 11/09, temos uma terceira atividade desempenhada por Yasmin, dessa vez ligada à organização de pedidos de auxílios para as crianças e financiamento habitacional. Os membros de sua comunidade encontram na protagonista informações que vêm de fora. Vale notar que nesse momento e também em outros que virão, o olhar da câmera se faz estranhado, isto é, deixa transparecer que não pertence àquela conjuntura, mas a outra. A forma com que as figuras humanas aparecem enquadradas no bairro pobre de tradição muçulmana, permite-nos entender que o foco narrativo se alinha àquilo que na literatura se convencionou chamar de uma descrição naturalista, o que acaba por silenciar e reduzir os membros da comunidade imigrante a situações de superficialidade.

Sendo assim, ao longo do filme, o narrador vai confirmando ser radicalmente o oposto daquilo que se dispõe a narrar: é citadino, ocidental, branco e de uma classe social mais favorecida. Sua narrativa lida com a elaboração das personagens através da estereotipação. Mesmo que se coloque bastante próximo à família Houssain, acaba por representar os imigrantes pobres pautando-se por modelos já estabelecidos em nosso imaginário ocidental, conferindo aos seus dramas cotidianos certa fragilidade, o que não assegura que componha a representação do "outro", pautando-se por seu arcabouço ideológico e cultural. Mais uma vez no cinema, surge um narrador (que aparentemente se propõe a conferir voz aos sujeitos marginalizados pela sociedade contemporânea, como é o caso da Europa e seus imigrantes), mas que na economia da obra não alcança ruptura na elaboração e representação dos orientais, ou mais especificamente, aqueles de tradição muçulmana em terras da rainha. Portanto, sua proximidade apenas indicia, e posteriormente, confirma um afastamento propositado, próprio de uma leitura do Oriente e seus imigrantes com as lentes ocidentais. Guardadas as devidas proporções, pode-se afirmar que o narrador de Yasmin (2004) é um orientalista. Feito tal diagnóstico, importa nos atentarmos às reflexões de Said (1990) como forma de orientação para o presente trabalho, uma vez que esse autor discute o conceito supragrifado.

${ }^{8}$ Interpolação nossa.

Construindo “ELes”: A NECESSIDADE DE...

H. J. dos Santos E L. H. Chaves $\bullet 183$ 


\section{A CONSTRUÇÃO DO ORIENTE PELOS OLHOS OCIDENTAIS: O JOGO CONSCIENTE DO NARRADOR?}

Said (1990) trata do conceito de "orientalismo", o que vem a ser um modo de visão e de estudo regularizado ou "orientalizado" que, dominado por imperativos, perspectivas e preconceitos político-ideológicos, foram adequados ao Oriente, e que podem ser rastreados no filme em análise. Sendo um produto de forças e interesses políticos, o orientalismo apresenta o Oriente como um sistema de representações dentro de um conjunto de forças que acabaram por introduzi-lo na consciência e na cultura ocidental. Said (1990) ateve-se a mostrar que o controle do orientalismo sobre o Oriente esteve presente na Europa desde a Antiguidade, determinando uma história cultural ${ }^{9}$, e seguiu como diretriz dos estudos ocidentais no século XIX. Tem-se, pois, a abordagem quanto à atitude orientalista como um alerta diante de representações e de ações geradas nessa lógica.

Ao tomar o orientalismo como um fato político e cultural, Said (1990) não trata de um tema ou de um campo de estudos, simplesmente. Relacionado e moldado pelo intercâmbio desigual de poderes político, intelectual, cultural e moral, o orientalismo não apenas representa, mas se torna "uma considerável dimensão da moderna cultura político-intelectual”, e como tal tem menos a ver com o Oriente que com o "nosso" mundo - o mundo ocidental. Segundo o autor há, nos textos mais diversos, uma distribuição de consciência geopolítica permeada por interesses. Nesse sentido, o Oriente é dado não só pela sua localização geográfica e pela sua diferenciação cultural, como também pela concepção do "outro" que adquiriu na construção político-ideológica do Ocidente.

A questão da imagem do "outro" é um dos marcos do orientalismo, ou talvez se possa dizer que é a sua máxima. Enfatizam-se as distinções entre generalizações dadas dividindo assim entre o "nosso" e o "deles" - seja quanto ao mundo ou à concepção de mundo - sempre em uma designação avaliativa. Tal interpretação muitas vezes corresponde à ação de concebermos o "deles" de acordo com o ponto de vista e em função do que é "nosso". Esse ponto é, pois, característico da atitude de dominação, uma vez que ao dizer do "outro" cria-se uma separação e um distanciamento propícios ao caráter hegemônico e à ação

\footnotetext{
${ }^{9}$ Em "Orientalismo: o oriente como invenção do ocidente", Said (1990, p. 13) analisa as experiências britânica, francesa e americana no Oriente, considerando-as como unidade dado o caráter imperialista e colonialista dessas experiências. Nesse contexto, trata da relação de autoridade tanto histórica quanto intelectual na concepção e na construção do orientalismo, o qual vem a ser, segundo o autor "[...] um modo de resolver o Oriente que está baseado no lugar especial ocupado pelo Oriente na experiência ocidental européia”.
} 
diante do que se crê primitivo e fraco. A imagem do "outro", então construída, cria conhecimentos - no âmbito intelectual e no senso comum - que são traduzidos em atitudes, possibilitando reações diversas de desrespeito e agressão de cunho preconceituoso. Nesse sentido, o orientalismo acaba por deslocar-se de uma atitude acadêmica para uma atitude instrumental, como no caso de certos conflitos culturais (SAID, 1990), de que é exemplo cabal o 11/09 e suas reverberações na sociedade ocidental contemporânea.

A relação Oriente-Ocidente é uma relação que comporta poder e dominação, marcada também por variados graus de uma hegemonia complexa, ou seja, por variadas formas de liderança cultural ${ }^{10}$. Uma vez que a hegemonia em ação resulta na durabilidade e na força do orientalismo como forma de dominação ocidental, Said considera "[...] hegemonia, um conceito indispensável para qualquer entendimento da vida cultural no Ocidente industrial [...]” (1990, p. 19). Portanto, a relação Oriente-Ocidente é dependente de uma vantagem relativa deste último, determinando assim, certa superioridade europeia sobre um suposto atraso oriental.

0 autor discute a relação dos trabalhos sobre o Oriente com os escritos antecedentes, o que acaba comprometendo qualquer análise como uma reprodução da autoridade já dada. Tal autoridade se faz na forma com que diversos estudiosos se relacionam com o tema: mantendo-se uma exterioridade, mesmo porque partem da concepção do "outro", a qual é carregada de distanciamentos e superioridades - ao invés da aproximação. A partir da atitude autoritária, que vem da localização ou da formação do ponto de vista do orientalista, o Oriente passa a ser dominado e representado pelo Ocidente. Dessa maneira, o que é dito e escrito nada mais é que "representação" - enfatiza o autor, como produto da exterioridade - e não descrições ou relatos antropológicos do Oriente; nesse sentido, pode-se afirmar a concepção de um Oriente entre aspas. Nas palavras de Said (1990, p. 32): "0 que ele diz e escreve, devido ao fato de ser dito e escrito, quer indicar que o orientalista está fora do Oriente, tanto existencial como moralmente. 0 principal produto dessa exterioridade é, claro, a representação [...]”.

Um ponto relevante nessa discussão é que os orientais não são tidos como indivíduos próprios de uma história, ou seja, de seu tempo e lugar, mas como identidades coletivas e generalizadas. Sendo assim, o autor adverte que como identidades coletivas generalizadas, os orientais são tidos ainda dentre pluralidades

\footnotetext{
${ }^{10} \mathrm{~A}$ atitude etnocêntrica para tratar de outras culturas senão a europeia marca o caráter hegemônico e imperialista a que se refere o autor: "[...] o orientalismo é fundamentalmente uma doutrina política imposta ao Oriente porque este era mais fraco que o Ocidente [...]" (SAID, 1990, p. 210).
}

Construindo “ELES": A NECESSIDADE DE...

H. J. dos Santos E L. H. Chaves 
humanas que acabam por reduzi-los e por contrapô-los: "[...] a distinção velha de séculos, entre a "Europa" e a "Ásia", ou "Ocidente" e "Oriente" carrega rótulos muito abrangentes [...]" (SAID, 1990, p. 163). Desse modo, o conhecimento de um orientalista passa por um processo de acumulação seletiva e um consenso de pesquisa, determinando então a reprodução das concepções e das representações criadas dentro desses rótulos e dos desvios já cometidos.

Feitas tais considerações sobre as potencialidades políticas, culturais e sociais do orientalismo, sua prerrogativa hegemônica de dominação na relação estabelecida entre o Oriente e Ocidente, em que o primeiro é (re) inventado pelo segundo; importa atentarmos às sugestões analíticas do próprio Said (1990), principalmente aquelas que tocam na representação dos sujeitos orientais na cultura contemporânea, de que nos valemos para pensar a película de Yasmin (2004). Assim introduzimos a quarta parte de nosso trabalho, dedicada às reverberações da queda das torres nova-iorquinas para os imigrantes muçulmanos e a forma com que o narrador cinematográfico "olha" para 0 assunto.

\section{Os ECOS DA QUEDA NA NARRATIVA}

A câmera visita a vila agora deserta. Yasmin segue seu percurso como 0 faz numa manhã como outra qualquer. Um som forte de helicóptero compõe a cena. A protagonista se troca enquanto do rádio de seu carro se ouve o discurso: "Entrei em contato com o vice-presidente, o ministro da Defesa, a equipe de Segurança Nacional e o meu gabinete. Não se iludam. Os EUA vão caçar e vão punir os responsáveis por esses atos covardes. Tomamos todas as precauções de segurança adequadas." Tal discurso é interrompido por Yasmin quando insere um CD no aparelho de som.

Um corte na imagem e Yasmin entra numa sala onde ficam os armários femininos da empresa em que trabalha. A personagem guarda suas coisas e pega um bilhete ali deixado para ela. Lê em voz alta: "Yas ama Osama". Demonstrando desconhecimento, ela ainda pergunta a suas colegas: "Quem é Osama?" Em seguida há risos tímidos na sala. Sem obter resposta, Yasmin se dirige com a mesma pergunta a John, que corrige sua pronúncia e esclarece: "Osama Bin Laden. As Tôrres Gêmeas, cara. Não tem TV na sua casa?" 0 bilhete é, dessa forma, a primeira manifestação de um discurso que vai tomando força na narrativa a partir de então.

0 fato de cidadãos ingleses representados pela película assimilarem a figura de 0sama - tido como responsável pelo ataque terrorista à Nova Iorque - à 
personagem paquistanesa de família muçulmana, revela uma identificação do "inimigo" no imaginário social. É acerca da construção de um inimigo comum ao Ocidente no pós 11/09 que a narrativa se propõe tratar. Paralelamente a discursos ouvidos em rádios e televisões sobre 0 ataque terrorista e as medidas políticas subsequentes desse, há um desencadeamento de fatos que levam as personagens pertencentes à família de Yasmin a situações limites. 0 que se estabelece, no percurso traçado pelo narrador, é a recorrente construção do inimigo a partir de discursos veiculados pela imprensa, ao passo que as personagens muçulmanas precisam comprovar sua inocência, isto é, de não serem partícipes do ataque. 0 que o narrador parece sinalizar é que a sociedade ocidental acabara tomando a parte pelo todo, culpando cada sujeito muçulmano pelo ato de autoria de terroristas advindos de países islâmicos.

Numa outra manhã, enquanto Yasmin dirige pelas ruas do bairro no mesmo percurso diário de mais um dia de trabalho, nota com estranhamento vans da polícia inglesa estacionadas entre veículos da comunidade, ao passo que dois policiais adentram em uma das casas vizinhas. Uma música dá tensão à cena e do rádio do carro se ouve: "E, de novo, em qualquer ação o objetivo será eliminar equipamentos militares, cortar financiamentos, suspender suprimentos... visando às tropas e não os civis". Como se percebe mais uma vez em outro discurso que provem de uma voz de rádio ou TV, ao mesmo tempo em que a câmera é posicionada para mostrar o bairro no qual moram as personagens centrais, enquanto Nasir canta.

0 ataque à nossa nação também foi um ataque aos ideais que fazem de nós uma nação. Nossa convicção nacional mais profunda é que cada vida é preciosa, porque cada vida é um presente do Criador que pretendia que vivêssemos em liberdade e igualdade. Isto nos diferencia do inimigo que combatemos. Nós valorizamos todas as vidas. Nossos inimigos não valorizam nenhuma. Nem as dos inocentes (YASMIN, 2004).

A representação do inimigo introjetada na sociedade inglesa, como é dada na narrativa, produz ecos. A cena que segue impressiona pela violência gratuita da apropriação do discurso, como o transcrito acima, por crianças. A tia de Yasmin, vestida com seu traje negro e usando o véu, é abordada por crianças de bicicletas na rua. As crianças a cercam e jogam nela algo como farinha, gritando: "Bruxa preta! Volte para o seu país! Dê o fora! Vá para casa! Quem vocêpensa que é? Escória paquistanesa! Bruxa preta!" 
A violência contra a mulher imigrante e muçulmana é, dessa forma, uma maneira encontrada pelo narrador de assinalar questões importantes como as vocalizações públicas de um discurso contra o imigrante muçulmano - que no início da película aparece pautado no anonimato - assim como a apropriação desse discurso como uma espécie de idealismo nacional sem as devidas mediações. Nesse sentido, é significativo que a cena opte pela agressão desempenhada por crianças. Todavia, não é apenas por meio da ingenuidade infantil que tal discurso é aderido, como já se adverte poucas cenas depois. Yasmin chega ao seu local de trabalho e se depara com sua foto pichada no quadro "funcionário do mês". Logo depois de encontrar em sua foto um desenho de barba e bigode, a protagonista encontra no carro em que trabalha transportando crianças a frase "Van do Talibã". No entanto, é numa conversa da personagem com John em uma festa que a narrativa aponta claramente o desentendimento criado no pós 11/09:

John: Não sabia que você vinha. Tomando vodca?

Yasmin: Comemorando.

John: Certo. 0 que está comemorando?

Yasmin: 0 assunto familiar. Está tudo resolvido.

John: Ótimo. Ótimo. [com uma expressão não muito animada]

Yasmin: Desistiu da ideia? Mudou de ideia agora que caímos de moda?

John: Não. É que foi meio repentino, só isso.

Yasmin: Pague outra bebida. Não sei por que vocês falam tanto. É horrível. [referindo-se à bebida alcoólica, que até então hesitava em experimentar] John: Você esqueceu a tônica.

[Yasmin o beija no rosto e se dirige às colegas sentadas em um sofá]: Tudo bem? Quais as novidades?

[Sentada Yasmin se dirige à TV que mostra um homem muçulmano]: Ei! Volte para 0 seu país, paquistanês!

[De volta para perto de John, Yasmin pergunta a ele]: 0 que há com eles? Um dia "funcionária do mês". Agora, sou inimiga número 1.

John: Eles só... Esquece!

Yasmin: Não entro numa mesquita há cinco anos. Sou tão muçulmana quanto você. Veja.

John: Eu sei, eu sei, eu sei! Vocês não estão facilitando, certo?

Yasmin: Quem?

John: Os muçulmanos. Ninguém apareceu e disse "desculpe", disse?

Yasmin: E por que os muçulmanos precisam se desculpar exatamente? 
John: Não comece, Yas.

Yasmin: Não. Vamos. Eu queria ouvir.

John: Foi feito em nome do... como se chama... Islã... certo?

Yasmin: Acha que eu devo me desculpar por ser muçulmana?

John: Vocês se juntaram e...

Yasmin: Você acha mesmo, não é?

John: Estou do seu lado, certo? Do seu lado!

Yasmin: Agora estamos tomando lados? Agora eu entendi!

[Yasmin volta-se para as pessoas ali presentes e grita]: Desculpe. Era isso que vocês queriam ouvir? Não fui eu. Não, não... [...] Eu sinto muito, muito mesmo. Eu não pilotei o avião, certo? Mas eu sinto muito. Agora está melhor? Está? Sinto muito! ${ }^{11}$ (YASMIN, 2004).

Antes de se dirigir à festa depois de se maquiar e sair de casa sem seu traje e seu véu - para o espanto do irmão que a vê desse jeito - Yasmin havia anunciado ao pai que se divorciaria de Faysal, o que gerou uma briga entre os dois. A decisão da protagonista se antecipou, tendo em vista a sua disposição em esperar o visto de legalidade de Faysal na Inglaterra, após uma tentativa do marido de se aproximar dela bêbado, o que acabou culminando numa agressão à Yasmin. Então disposta a se aproximar de John, a personagem se arruma e vai à festa. Todavia, com a reação de John fica claro para Yasmin que os reflexos do 11/09 atingiam diretamente a sua vida.

Nesse sentido, o diálogo transcrito acima denuncia uma provável interpretação para o título do filme no Brasil "Yasmin: uma mulher, duas vidas". 0 ataque às torres gêmeas dava início a uma nova vida para a personagem. Não por acaso, nesta noite Yasmin não consegue dormir e quando senta diante da televisão acaba por ouvir um canal que, enquanto transmitia as torres nova-iorquinas em chamas, dizia: "Poderíamos entrar em guerra por uma religião. Eu sugeriria mais que isso. Por uma cultura. O Islã agora é algo temível, suspeito. É como ser um católico irlandês... um terrorista... ou um simpatizante do terrorismo". A câmera foca o olhar perplexo da protagonista. 0 mundo ocidental entrara em guerra contra uma religião: a sua ${ }^{12}$.

\footnotetext{
${ }^{11}$ Interpolações nossa.

${ }^{12}$ A justaposição de termos como "islã", "muçulmanos" e "terroristas" na narrativa vem denunciar confusões terminológicas que, consequentemente, comprometem a compreensão de fatores distintos como religião, cultura, política e de guerra santa (jihad). Acerca dessa discussão, ver Demant (2008). Nesse sentido, a sobreposição do ato de terrorismo à religião islâmica - como 
0 que se declarava na imprensa refletia diretamente no dia a dia da personagem e da sua família, assim como na vida de outros moradores do bairro habitado essencialmente por imigrantes paquistaneses e descendentes desses. Como é representado na narrativa, o preconceito que antes existia veio à tona com o ataque terrorista, levando as personagens de raízes muçulmanas a situações limites, como a invasão de policiais na casa de Yasmin e de seu pai.

Yasmin é levada à delegacia juntamente com John, que no momento visitava a amiga. Faysal, por quem a polícia procurava, ao encontrar a casa revirada pede ajuda aos dois policiais que o conduzem, dizendo que poderiam ajudá-lo a encontrar a esposa. Faysal é preso sob a acusação de envolvimento com organização terrorista, e John e Yasmin são interrogados. A protagonista é mantida na cadeia após a argumentação do investigador de que a mesma estaria acobertando o marido: "Pelo Ato Antiterrorismo de 2001, posso acusá-la de sonegar informações". Depois de ser encarcerada e novamente interrogada, a personagem é libertada com a seguinte proposta:

Investigador: Diga que se casou contra vontade, e eu o faço assinar os papeis. [referindo-se aos documentos necessários para o divórcio que Yasmin levava consigo com a pretensão de que Faysal os assinasse] Ele volta para 0 Paquistão, sem acusações, um homem livre. E você volta para sua vida, como era antes ${ }^{13}$.

Yasmin: Antes, ele era inocente. E eu também (YASMIN, 2004).

Tal declaração é significativa para a narrativa, uma vez que o "antes" se refere ao antes do 11/09. 0 narrador aponta, a partir de então, uma nova postura da personagem que, após sofrer com as intolerâncias consequentes do ato terrorista, retoma algumas práticas muçulmanas como ler o Alcorão, cobrir-se com o véu e frequentar a mesquita. É, pois, relevante para a diegese que em seu desfecho se encene um último encontro entre Yasmin e John. Ao esbarrar com a colega de trabalho, John diz surpreso: "Yas! Não reconheci você no seu... traje." A câmera foca no rosto de John que não esperava vê-la com vestimentas que antes a personagem não usava perto dele, ao mesmo tempo em que focaliza a expressão de Yasmin que espera ser reconhecida e, como em sua última tentativa de se

é dado pelo discurso elencado pela narrativa aqui analisada - marca uma enorme confusão entre questões políticas e culturais que criam no imaginário social associações que servem tão somente à rivalidade entre povos: justamente o que tenta demonstrar a referida obra cinematográfica.

${ }^{13}$ Interpolação nossa. 
aproximar do pretendente, anuncia que conseguiu o divórcio. Mas John expressa certa reprovação quando a protagonista o convida para ir à mesquita:

Yasmin: Então, a gente se vê, certo?

John: Provavelmente, não (YASMIN, 2004).

\section{CONSIDERAÇÕES FINAIS}

Como foi possível analisar, em cada objeto de cultura, e neste caso, em cada filme, há uma visão de mundo orquestradora. Sua tônica pode ser esquadrinhada a partir de uma análise cinematográfica, a qual levou em consideração as relações estabelecidas entre o cinema e a sociedade, que por sua vez, fornece matéria e substancialidade a primeiro, conforme intentamos observar e descrever ao longo desse trabalho. Portanto, é pelos olhos, ou melhor, pelas lentes do narrador fílmico que conhecemos o conteúdo narrativo de cada filme, mas é também por meio dessa instância narradora e a forma com que elabora seu relato que pudemos rastrear seu modo de pensar e representar a realidade que o cerca. Claro está que isso não deixa de se alinhar a fatores externos à obra, ou melhor, o próprio terreno social do qual parte o cineasta, e os dilemas de tempo e espaço lá presentes, capturados e artisticamente relidos, o que vai compondo e fornecendo elementos para 0 argumento a ser perseguido pela economia interna do filme.

No caso do narrador de Yasmin (2004), pode-se afirmar que o mesmo constrói certa armadilha ao longo de sua narrativa, conscientemente elaborada. Embora se coloque próximo à comunidade de imigrantes muçulmanos alocados em um bairro periférico da Inglaterra hodierna, selecionando os dilemas vividos por Yasmin, sua família e comunidade, o foco narrativo não se desvencilha de sua visão de mundo ao representar o "outro". Segundo pudemos apontar ao longo desse artigo, o filme sustenta certa exterioridade ao trazer a cena sujeitos excêntricos, dispostos pela marginalidade e pobreza da sociedade inglesa do início do século XXI. A narrativa compõe e mostra personagens por meio dos estereótipos, sendo elas carregadas de características tipificadas. Isso delega e condiciona tais indivíduos à superficialidade. Em Yasmin (2004) fica visível a condição ocidentalizada do ponto de vista construído ao longo do filme, que parece partir da concepção do "outro" como sujeito apartado do meio em que está contextualizado, como se sua trajetória e os próprios fatores históricos não influíssem para o "estado das coisas". Importa destacar que o entendimento do narrador sobre os imigrantes muçulmanos é impregnado de distanciamentos e 
reitera uma estratégia de dominação - dessa vez cultural -, ao passo que almeja transparecer aproximação, afeto e naturalidade.

Dessa forma, o filme e seu narrador manifestam e reiteram o orientalismo, tal como discutiu Edward W. Said; para o qual rótulos como "islã", "árabe" ou "muçulmano" usados como subdivisões do "Oriente" carregam significados que, determinados pela história, pela política e pela religião, exigem mediações que filtrem os objetos designados por tais rótulos.

Em suma, o filme Yasmin (2004) acaba por interpretar a condição de imigrantes muçulmanos idealizando aquilo que é "deles" a partir da perspectiva e em função do que é "nosso". Temos então, mais uma vez, um objeto de cultura reiterando uma atitude de dominação, já que ao se dispor a representar o "outro", cria uma fratura e um afastamento propícios ao caráter hegemônico e à ação diante do que se crêprimitivo, fraco e frágil. Vale destacar que a imagem do "outro", então arquitetada, cria representações - no âmbito intelectual e principalmente no senso comum - que são traduzidos em atitudes, possibilitando reações diversas de intolerância e agressão de cunho preconceituoso.

\section{REFERÊNCIAS}

DEMANT, Peter. O mundo muçulmano. São Paulo: Contexto, 2008.

JAMESON, Fredric. O inconsciente politico: a narrativa como ato socialmente simbólico. Tradução de.Valter Lellis Siqueira. São Paulo: Ática, 1992. . As marcas do visivel. Rio de Janeiro: Graal, 1995.

SAID, Edward. W. Orientalismo: o oriente como invenção do ocidente. São Paulo: Companhia das Letras, 1990.

XAVIER, Ismail. O discurso cinematográfico: a opacidade e a transparência. Rio de Janeiro: Paz e terra, 1977.

XAVIER, Ismail. Cinema: revelação e engano. In: . O olhar e a cena. São Paulo: Cosac e Naify, 2003. p. 31-57.

YASMIN. Alemanha e Inglaterra. Direção: Kenneth Glenaan. Produção: Parallax Independent. Intérpretes: Archie Panjabi, Renu Setna, Steve Jackson, Syed Ahmed, Shahid Ahmed, Badi Uzzaman, Amar Hussain, Joanna Booth, Emma Ashton, Rae Kelly, Tammy Barker e outros. Roteiro: Simon Beaufoy. 2004 (80 min), son., color. 